\title{
Behaviour of Market Arrivals and Prices of Bengal Gram in Kalaburagi District of Karnataka: An Economic Analysis
}

\author{
M. Satishkumar ${ }^{1 *}$, Ravi Pujari $^{2}$ and Amaresh ${ }^{1}$ \\ ${ }^{1}$ Department of Agricultural Economics, ${ }^{2}$ Department of Horticulture, CoA, \\ Bheemarayanagudi, UAS, Raichur, India \\ *Corresponding author
}

\section{A B S T R A C T}

\section{Keywords}

Arrivals, Bengal gram, Correlation,

Seasonal Indices,

Variability

\section{Article Info}

Accepted:

04 August 2020

Available Online:

10 September 2020
This study has been carried out to examine the variability pattern of market arrivals and prices of bengal gram in Kalaburagi district of Karnataka and also to analyse the relationship between market arrivals and prices. The present study is based on market arrivals and prices of bengal gram collected from the Kalaburagi market for the period 2005-2019. The study has shown that the mean monthly arrival of bengal gram was highest in the month of February and lowest in the month of November. The price variability was found highest in the year 2016 . The results of the study showed the negative correlation between market arrivals and prices across months. The seasonal indices of the arrivals were high during the month of January to April and the price indices were high during the month of July to December.

\section{Introduction}

Bengal gram is the major pulse crop grown in Karnataka state. It is a protein rich supplement to all cereal based diet, especially for vegetarians. It was cultivated in an area of 12.65 lakh hectares with a total output of 9.75 lakh tones in Karnataka during the year 201718. The area and production are fluctuating year after year due to high incidence of pest and diseases, rainfed condition and fluctuating marketing prices (Kiresur et al., 2009).

The price of agricultural commodities assumes to have great significance from producer's as well as consumer's point of view (Navasare et al., 2018).

The variation in the prices of agriculture commodities has been one of the major factors affecting the income levels of the Indian farmers.

The interrelation between the arrival and prices of agriculture commodities is required for assessing the extent of price fluctuations over a time. Therefore, the present study aims to examine the behaviour of market arrivals and prices of bengal gram in Kalaburagi district of Karnataka. 


\section{Materials and Methods}

Kalaburagi district of Karnataka was selected for this study because it is one of the highest bengal gram producing district of Karnataka.

The district produced nearly 2.30 lakh tonnes of bengal gram from an area of 2.06 lakh hectares during the year 2017-18. Secondary time series data on market arrival and price of bengal gram for the period of 2005-2019 was collected from the www.krishimaratavahini. kar.nic.in. The behaviour of market arrivals and price of the bengal gram was analysed in terms of mean value for each month and the coefficient of variation.

The degree of relationship between market arrivals and prices was computed by correlation coefficient.

The seasonal indices of monthly average arrivals and prices of bengal gram in Kalaburagi market was worked out to study the seasonal variations.

\section{Results and Discussion}

Monthly variability in market arrivals and prices of bengal gram in Kalaburagi district of Karnataka

The monthly variability in the arrivals and prices of bengal gram in Kalaburagi market of Karnataka is presented in Table 1. The results revealed that the mean monthly arrival of bengal gram was highest in the month of February with 47030.33 quintals and lowest in the month of November with 11571.27 quintals. Similar results were reported by Chandana (2016) in her study. The variability in the market arrivals was higher with values of coefficient of variation fluctuating between 152.93 per cent in September to 45.38 per cent in January. Similarly, the mean price of bengal gram was ranged from Rs. 3043.33/q in February to Rs. 3634.73/q in September. The monthly price variability remained very high during the month of November (49.66\%) and it was low in the month of March (36.14\%).

Table.1 Monthly variability in market arrivals and prices of bengal gram in Kalaburagi district of Karnataka, 2005-2019 (15 years)

\begin{tabular}{|l|r|r|r|r|}
\hline \multirow{2}{*}{ Months } & \multicolumn{2}{|c|}{ Arrivals } & \multicolumn{2}{c|}{ Prices } \\
\cline { 2 - 5 } & Mean & CV (\%) & \multicolumn{1}{c|}{ Mean } & CV (\%) \\
\hline January & 35747.80 & 45.38 & 3236.07 & 42.84 \\
\hline February & 47030.33 & 54.31 & 3056.33 & 36.90 \\
\hline March & 34111.40 & 67.28 & 3043.33 & 36.14 \\
\hline April & 27103.27 & 56.98 & 3186.20 & 42.13 \\
\hline May & 18293.47 & 59.97 & 3230.87 & 44.24 \\
\hline June & 15087.53 & 61.04 & 3185.53 & 44.22 \\
\hline July & 13838.00 & 63.60 & 3532.73 & 47.97 \\
\hline August & 13887.80 & 76.82 & 3591.80 & 44.09 \\
\hline September & 22105.93 & 152.93 & 3634.73 & 46.68 \\
\hline October & 13602.33 & 72.67 & 3591.07 & 49.02 \\
\hline November & 11571.27 & 85.13 & 3560.53 & 49.66 \\
\hline December & 13142.13 & 76.72 & 3514.87 & 45.53 \\
\hline
\end{tabular}


Table.2 Yearly variability in market arrivals and prices of bengal gram in Kalaburagi district of Karnataka, 2005-2019 (15 years)

\begin{tabular}{|c|c|c|c|c|}
\hline \multirow{2}{*}{ Years } & \multicolumn{2}{|c|}{ Arrivals } & \multicolumn{2}{c|}{ Prices } \\
\cline { 2 - 5 } & Mean & CV (\%) & Mean & CV (\%) \\
\hline $\mathbf{2 0 0 5}$ & 9458.25 & 175.32 & 1750.92 & 08.75 \\
\hline $\mathbf{2 0 0 6}$ & 10500.83 & 130.49 & 2188.17 & 17.66 \\
\hline $\mathbf{2 0 0 7}$ & 3668.17 & 67.21 & 2189.58 & 04.42 \\
\hline $\mathbf{2 0 0 8}$ & 13566.08 & 100.00 & 2231.50 & 09.61 \\
\hline $\mathbf{2 0 0 9}$ & 28718.92 & 74.35 & 2205.25 & 07.62 \\
\hline $\mathbf{2 0 1 0}$ & 36353.67 & 87.10 & 2144.17 & 08.63 \\
\hline $\mathbf{2 0 1 1}$ & 24807.92 & 48.57 & 2792.58 & 18.07 \\
\hline $\mathbf{2 0 1 2}$ & 15514.42 & 98.58 & 4413.50 & 16.33 \\
\hline $\mathbf{2 0 1 3}$ & 36494.33 & 43.76 & 3278.83 & 06.59 \\
\hline $\mathbf{2 0 1 4}$ & 35263.00 & 58.39 & 2830.42 & 05.84 \\
\hline $\mathbf{2 0 1 5}$ & 25465.25 & 44.04 & 4379.58 & 13.59 \\
\hline $\mathbf{2 0 1 6}$ & 21076.08 & 51.09 & 6657.58 & 24.91 \\
\hline $\mathbf{2 0 1 7}$ & 18995.00 & 64.68 & 5306.25 & 14.42 \\
\hline $\mathbf{2 0 1 8}$ & 30759.50 & 113.36 & 3789.67 & 10.12 \\
\hline $\mathbf{2 0 1 9}$ & 21260.17 & 30.99 & 4297.08 & 06.10 \\
\hline
\end{tabular}

Table. 3 Correlation coefficient ( $\mathrm{r}$ ) between arrivals and prices of bengal gram in Kalaburagi district of Karnataka, 2010-2019 (10 years)

\begin{tabular}{|l|c|}
\hline Months & Correlation coefficient (r) \\
\hline January & -0.546 \\
\hline February & $-0.737 *$ \\
\hline March & -0.330 \\
\hline April & -0.448 \\
\hline May & -0.102 \\
\hline June & -0.383 \\
\hline July & -0.456 \\
\hline August & -0.371 \\
\hline September & -0.078 \\
\hline October & -0.627 \\
\hline November & -0.591 \\
\hline December & -0.397 \\
\hline Note $*$ Signific|
\end{tabular}

Note: *Significant at $5 \%$ level of significance 
Table.4 Seasonal indices of arrivals and prices of bengal gram in Kalaburagi district of Karnataka, 2005-2019 (15 years)

\begin{tabular}{|l|c|c|}
\hline \multicolumn{1}{|c|}{ Months } & Arrival Index & Price Index \\
\hline January & 190.32 & 97.58 \\
\hline February & 226.05 & 92.79 \\
\hline March & 159.38 & 92.57 \\
\hline April & 119.36 & 94.96 \\
\hline May & 81.14 & 95.21 \\
\hline June & 64.84 & 94.26 \\
\hline July & 62.26 & 103.64 \\
\hline August & 58.20 & 106.19 \\
\hline September & 85.10 & 106.95 \\
\hline October & 52.75 & 105.61 \\
\hline November & 44.60 & 104.48 \\
\hline December & 55.99 & 105.74 \\
\hline
\end{tabular}

Yearly variability in market arrivals and prices of bengal gram in Kalaburagi district of Karnataka

The variability in arrival and prices of bengal gram in Kalaburagi district of Karnataka from the year 2005 to 2019 was depicted in Table 2. The results revealed that the market arrival was highest in the year 2013 with a mean of 36494.33 quintals and lowest in the year 2007 with a mean of 3668.17 quintals. The variation was highest in the year 2005 (175.32 $\%)$ and lowest in the year 2019 (30.99\%). The result also indicated that the market price was highest in the year 2016 with an average price of Rs. 6657.58/q and lowest in the year 2005 (Rs. 1750.92/q). The price variability also showed inter-year price fluctuations. The variation was found highest in the year 2016 $(24.91 \%)$ and lowest in the year 2007 (4.42 $\%)$.

\section{Relationship between market arrivals and prices}

The correlation coefficient ( $r$ ) was used to study the inter-relationship between monthly arrivals and monthly prices of bengal gram (latest 10 years data) in Kalaburagi district of Karnataka and the results are presented in the Table 3. The results revealed that the correlation coefficients between arrivals and prices were negative for all of the month but the statistical significance was noticed only for one month. Similar results were reported by Navasare et al., (2018) in their study.

Seasonal indices of arrivals and prices of bengal gram in Kalaburagi district of Karnataka

The seasonal indices of arrivals and prices of bengal gram in Kalaburagi district of Karnataka are presented in the Table 4. The seasonal indices of arrivals were high during the month of January to April. The highest arrival index was noticed in the month of February (226.05). The minimum arrival was in October with an arrival index of 52.75 . Whereas, the price indices were noticed high during the month of July to December and the highest value was observed during the month of September (106.95). The inverse relationship between the arrivals and prices can be noticed from the table. When there were more arrivals in the market, the price 
was comparatively lower. The findings of Asmatoddin et al., (2009) aptly support the findings of the current study.

The present study concludes that the market arrivals of bengal gram in Kalaburagi district of Karnataka were high in the months of January to March. The extent of variability is high in the month of September and low during the months of January and February. The yearly variation was found highest in the year 2016 and lowest in the year 2007. There was a negative relationship between arrivals and prices of bengal gram in the market. The seasonal indices of arrivals were high during the month of January to April. But the price indices were noticed high during the month of July to December.

\section{References}

Asmatoddin Mohd., Satpute, T. G. and Maske, V. S., 2009, Arrival and Price Behaviour of Important Pulse Crops in Parbhani District. Int. J. Agricul. Sci., 5 (2): 428-430.

Chandana, C. M., 2016, an Economic Evaluation of Market Arrivals and Prices of Pulses in Latur District of Maharashtra State. Int. J. Curr. Res., 8 (2): 25929-25931.
Divya, K., Rajeswari, S., Bhavani Devi, I. and Sumathi, P., 2017, Forecasting Monthly Prices of Bengalgram in Selected Markets of Andhra Pradesh. Int. J. Res. Agricul. Sci., 4 (4): 2348 3997.

Kiresur, V. R.,.Kulkarni, G. N. And Kulkarni, V. S., 2009, Baseline Assessment of Chickpea for Karnataka State in India. Baseline research report for Tropical Legumes-II. ICRISAT, pp 150. www. icrisat.org/tropicallegumesII.

Navasare, D. J., Perke, D. S. and Shelke, R. D., 2018, Growth Performance of Arrivals and Prices of Sorghum, Tur, Soybean, Chickpea and Bajra in Ahmednagar District, India. Int. J. Curr. Microbiol. Appl. Sci, 7 (7): 3697-3701.

Rachana Patil, and Vineel Bhurke, 2014. Economic Analysis of Arrivals and Prices of Pulses in Maharashtra State of India. Res. J. Econ. Bus. Stud., 3 (7): 20-24.

Thakar, K. P., Singh Shiv Raj, Soumya, C. and Chaudhari Dinesh, D., 2017, An Economic Analysis of Price Movement of Major Pulse Crops of North Gujarat. Int. J. Agri. Sci., 9 (30): 4422-4426.

\section{How to cite this article:}

Satishkumar, M., Ravi Pujari and Amaresh. 2020. Behaviour of Market Arrivals and Prices of Bengal Gram in Kalaburagi District of Karnataka: An Economic Analysis. Int.J.Curr.Microbiol.App.Sci. 9(09): 79-83. doi: https://doi.org/10.20546/ijcmas.2020.909.009 